\title{
FLUORIDATION OF THE PUBLIC WATER SUPPLY AND PREVALENCE OF DENTAL FLUOROSIS IN A PERIPHERAL DISTRICT OF THE MUNICIPALITY OF BAURU, SP
}

\author{
FLUORETAÇÃO DA ÁGUA DE ABASTECIMENTO PÚBLICO E PREVALÊNCIA DE \\ FLUOROSE DENTÁRIA EM BAIRRO DA PERIFERIA DE BAURU, SP
}

Irene RAMIRES ${ }^{1}$, Kelly Polido Kaneshiro OLYMPIO², Andréa Gutierrez MARIA ${ }^{3}$, Juliano Pelim PESSAN4, Vanessa Eid Silva CARDOSO ${ }^{5}$, Carolina Simonetti LODI ${ }^{6}$, Marília Afonso Rabelo BUZALAF ${ }^{7}$

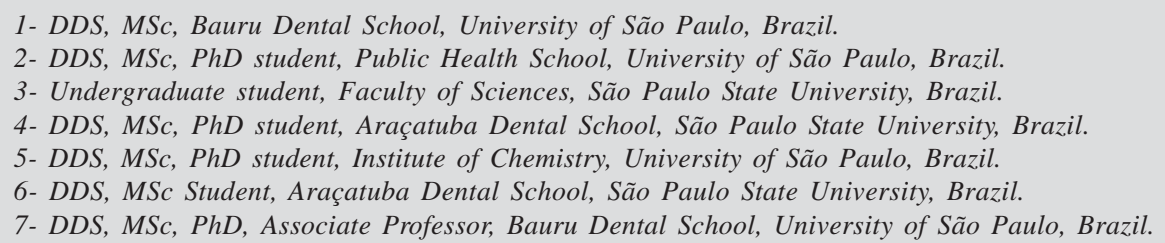

Corresponding address: Profa. Dra. Marília Afonso Rabelo Buzalaf - Universidade de São Paulo - Faculdade de odontologia de Bauru Departamento de Ciências Biológicas, Área de Bioquímica - Alameda Dr. Octávio Pinheiro Brisolla, 9-75

Cep.: 17. 012-901 Bauru SP Brasil - e-mail:mbuzalaf@fob.usp.br

Received: July 07, 2005 - Modification: January 31, 2006 - Accepted: March 21, 2006

\begin{abstract}
$O$ bjectives: The objectives of this study were to assess the fluoride concentration in the public water supply and the prevalence of dental fluorosis in schoolchildren between 7 and 15 years old, living in a peripheral district of the municipality of Bauru. Material and Methods: For this, fifty two water samples were collected on three different days of one week. These samples were analyzed for fluoride by means of the ion-sensitive electrode method (Orion 9609) coupled to a potentiometer (Procyon, model 720). In this method, $1.0 \mathrm{~mL}$ of TISAB II (Orion) was added to $1.0 \mathrm{~mL}$ of the sample. For the epidemiological survey of fluorosis, 52 schoolchildren of both genders, aged between 7 and 15 were assessed, with prior authorization from their caretakers. Only one person examined the children, after supervised toothbrushing and drying with cotton wool rolls. The TF index was used. Results: The fluoride concentrations in the water samples ranged from 0.62 to $1.20 \mathrm{mg} / \mathrm{L}$, with a mean of $0.9 \mathrm{mg} / \mathrm{L}$. The prevalence of dental fluorosis was 33\%, with severity ranging from TF1 to TF4 (Kappa of 0.73 and concordance of $83.33 \%$ ). Conclusions: The results from the analysis of water samples indicated a fluoride concentration greater than recommended for Bauru. The fluorosis levels found were higher than expected for a peripheral district, in which water is one of the few sources of fluoride.
\end{abstract}

Uniterms: Fluoride; Fluoridation; Epidemiology; Fluorosis; Sanitary surveillance.

\begin{abstract}
RESUMO
$\mathrm{O}$

bjetivos: Avaliar a concentração de flúor na água de abastecimento público e a prevalência de fluorose dentária de escolares entre 7 e 15 anos de idade, residentes em um bairro da periferia de Bauru. Matérial e Métodos: Foram coletadas 52 amostras de água durante três dias de uma semana e analisadas utilizando-se o eletrodo íon sensível (Orion 9609), acoplado a um potenciômetro (Procyon, modelo 720), com 1,0 $\mathrm{mL}$ da amostra à qual foi adicionado $1,0 \mathrm{~mL}$ de TISAB II (Orion). Para o levantamento epidemiológico de fluorose foram examinados 52 escolares entre 7 e 15 anos de idade, de ambos os gêneros, mediante a obtenção de autorização prévia dos responsáveis. Somente um examinador realizou os exames após escovação supervisionada e secagem dos dentes com rolos de algodão. O índice utilizado foi o TF, estabelecido a partir do grau máximo verificado em cada indivíduo. Resultados: A concentração de flúor na água variou entre 0,62 e 1,15 mg/ L, mantendo uma média de $0,9 \mathrm{mg} / \mathrm{L}$. A prevalência de fluorose dentária verificada foi de 33\%, com severidade variando entre TF1 e TF4 (Kappa=0,73 e concordância de 83,33\%). Conclusões: Os resultados da análise das amostras de água indicam uma concentração média de flúor acima do recomendado para Bauru. O índice de fluorose dentária verificado foi maior que o esperado para um bairro da periferia, onde a água é uma das poucas fontes de ingestão de flúor.

Unitermos: Flúor; Fluoretação; Epidemiologia; Fluorose; Vigilância sanitária.
\end{abstract}




\section{INTRODUCTION}

The therapeutic effects of fluoride, which are widely recognized in public health interventions, are greater when water is used as the vehicle, because of its wide public distribution, effectiveness, cost and frequency of consumption ${ }^{2,16,17,24}$. According to the Centers for Disease Control and Prevention (CDC) in the United States, the fluoridation of the public water supply is one of the ten most important public health achievements in the twentieth century ${ }^{5}$.

However, it is important to emphasize that fluoride is a chemical element. Therefore, because of its different levels of acute and chronic toxicity (which are dependent upon the dose and length of exposure), its addition to the public water supply needs to be rigorously monitored at all times, so as to maintain caries control and prevent dental fluorosis $^{2,11}$.

Dental fluorosis is one of the effects resulting from chronic fluoride intoxication, caused by excessive intake at the periods of enamel formation. It is associated with the capacity of fluoride to act on ameloblasts during the maturation phase of the developing enamel. Fluoride can be ingested from many sources; such as water, toothpaste, soft drinks, juices and foods. This variety of sources increases the predisposition towards the occurrence of fluorosis, in comparison with situations in which access to fluoride is solely by means of fluoridated water. The prevalence of fluorosis is directly proportional to fluoride intake, and it is influenced by certain environmental factors ${ }^{1,7}$.

Large numbers of studies have described the positive association between places with a fluoridated water supply and the occurrence of fluorosis. Its prevalence is directly proportional to the fluoride concentration in the water, especially in cases when fluoride concentrations in water are above the optimum levels, $4,8,10,14$.

The study by Ramires ${ }^{20}$ (2004), carried out on the municipality of Bauru during the years of 2003 and 2004, with water collection in May, August and November 2003 and February 2004, confirmed the need for a more detailed study of the area supplied by the well "Parque Real I", since a high fluoride concentration was found in all of its water samples. The fluoride concentration in the water from this well, which supplies the Parque Real district, ranged from 0.89 to $16.30 \mathrm{mg} / \mathrm{L}$. Although this is a small area, there is a large number of children among the residents, and therefore a high risk of fluorosis seemed evident.

In the view of what is outlined above, this study had the objectives of analyzing the water that supplies homes in the Parque Real district and verifying the prevalence and severity of dental fluorosis among schoolchildren aged between 7 and 15 years of age, living in the district. Specific study of the area allows important data to be obtained, so that immediate measures can be taken in order to maintain the fluoride level in water between 0.6 and $0.8 \mathrm{ppm}$, which is essential for the control of dental caries and prevention of fluorosis.

\section{MATERIALAND METHODS}

\section{Assessment of fluoride concentration in the water}

Samples of water were collected from 52 homes out of approximately 150 homes in the area of the well "Parque Real I”. The collection was performed only after the person living in that home had read the statement of free and informed consent and had signed it, thereby authorizing the collection of water. Homes were randomly chosen by drawing.

\section{Collection of water samples}

For collection of water samples, $50 \mathrm{~mL}$ plastic vials were utilized, after labeling in order to identify the place and date of sampling. The collection took place during the second week of January 2004, over three days (Monday, Wednesday and Friday). The collection point chosen was just after the water meter device, and thus before the water reached the water tank, in order to reproduce the conditions under which the water arrives at the home. After collection, the samples were stored in a chamber at $-20^{\circ} \mathrm{C}$ and subsequently analyzed.

The residents of these homes received information leaflets about fluoridation of the public water supply and dental fluorosis.

\section{Fluoride analysis}

The fluoride concentrations in the water samples was determined in duplicates, using the ion-sensitive electrode (Orion 9609) coupled to a $\mathrm{pH} / \mathrm{F}$ potentiometer (Procyon, model 720). In this method, $1.0 \mathrm{~mL}$ of TISAB II (Orion) was added to $1.0 \mathrm{~mL}$ of the sample. To define the calibration curve, the following standard solutions were used: $0.1,0.2$, 0.4, $0.8,1.6$ and 3.2 ppm of fluoride. To check the calibration, hourly tests were performed, using solutions of known fluoride concentrations. The readings were obtained in $\mathrm{mV}$ and then converted to $\mu \mathrm{g}$ of fluoride by means of the Excel software (Microsoft). The mean value for the readings obtained from the standards was inserted in the worksheet and the percentage concordance was then calculated. Concordance values of over $90 \%$ for all standards were accepted. The slope of the electrode was checked before each step of the readings. The results from the analyses of water samples were checked by means of a new reading of $10 \%$ of the samples (to check reproducibility).

\section{Sample classification}

The fluoride level found in the samples was used to classify them as "acceptable" or "unacceptable", according to the criterion defined by Ramires ${ }^{20}$ (2004).

\section{Epidemiological survey}

Prior to performing the study, the project was submitted to and approved by the research ethics committee of Bauru Dental School, University of São Paulo. A group of 52 schoolchildren of both genders, aged between 7 and 15 years, was examined after obtaining authorization from the 
persons responsible for them. The criteria adopted for sample selection were that the subjects should be available to participate in the study, be within the age group established and have been born in the district. The examinations were performed during July 2004.

\section{Examination}

A single examiner performed all examinations. Prior to examinations, intraexaminer variation was evaluated using the Kappa test (Kappa of 0.73 and concordance of $83.33 \%$ ), after re-examining 10 volunteers of the total (52 schoolchildren). The volunteers brushed their teeth supervised by a community health student. The teeth were then dried using cotton wool rolls. All schoolchildren received a toothbrush and a tube of toothpaste for brushing. Oral examination was performed under natural light in a house in the district, which does not have any school or even a health unit. It was done by visual inspection, utilizing an exploratory probe as recommended by the WHO, a plane mirror and a tongue depressor. During the examinations, the volunteers were seated on chairs.

The TF index was utilized, in which all buccal surfaces of permanent teeth were examined. Teeth with fillings and/or those with less than $2 / 3$ of the crown exposed were excluded from the sample. The degree of fluorosis was established from the highest value found in each individual.

\section{Statistical analysis}

This was done by means of descriptive statistics, using the SPSS software.

\section{RESULTS}

Table 1 shows the results from the classification of water samples according to the fluoride concentration. It can be noticed that around $69 \%$ of samples were classified as inappropriate and $2 \%$ were unacceptable, meaning that $71 \%$ of samples were above the limit that is considered as appropriate for the municipality (fluoride content of more than $0.84 \mathrm{mg} / \mathrm{L}$ ).

Table 2 shows the results of the dental fluorosis survey, which found a prevalence of 33\%. The degree of severity

TABLE 1- Classification of water samples, $n$ and \%, according to fluoride levels, Bauru, 2004

\begin{tabular}{llll} 
Fluoride level (mg/L) & $\mathbf{n}$ & $\%$ & Classification \\
\hline $0 \mid-0.55$ & 0 & 0 & Unacceptable \\
$0.55 \mid-0.65$ & 2 & 4 & Under-optimal \\
$0.65 \mid-0.75$ & 3 & 6 & Optimal \\
$0.75 \mid-0.85$ & 10 & 19 & Supra-optimal \\
$0.85 \mid-1.15$ & 36 & 69 & Inappropriate \\
$1.15 \mid-$ or more & 1 & 2 & Unacceptable \\
Total & 52 & 100 & \\
\hline
\end{tabular}

ranged from TF1 to TF4: $11 \% \mathrm{TF} 1,8 \% \mathrm{TF} 2,12 \% \mathrm{TF} 3$ and 2\% TF4.

Table 3 shows the percentages of the different degrees of fluorosis according to the dental group. In this, TF1, TF2, TF3 and TF4 were observed in incisors and premolars (11.5\% and $11.4 \%$, respectively), canines and premolars (6.9\% and $14.3 \%$, respectively), incisors and canines (9.6\% and 6.9\%, respectively) and premolars (2.9\%).

\section{DISCUSSION}

The municipality of Bauru has a singular water supply system consisting of 27 wells and one water treatment station. The system comprises 19 supply sectors. The difficulty in maintaining appropriate levels of fluoride in the water is evident and has been reported in some studies,20,22.

Bauru is located in the southeastern region of Brazil and in the middle western part of the State of São Paulo. The annual average temperature is $26^{\circ} \mathrm{C}$, with a winter average of $17^{\circ} \mathrm{C}$ and a summer average of $30^{\circ} \mathrm{C}$. According to Resolution SS-250/95, dated 15/08/95, the water in municipalities of the State of São Paulo must have a fluoride content of $0.7 \mathrm{mg} / \mathrm{L}$, and the defined range of acceptable levels is from 0.6 to $0.8 \mathrm{mg} / \mathrm{L}^{21}$.

Thus, around $72 \%$ of the water samples from homes in Parque Real district presented inappropriate fluoride levels, with a mean fluoride concentration of $0.9 \mathrm{mg} / \mathrm{L}$ (Table 1 ). There is a singularity in the fluoridation method of the water that supplies the area. The district of Parque Real is located in Sector II, which is supplied by the wells Parque Real I and Parque Real II. Although it is registered that the sector is supplied by both wells, only a small proportion of the population of this sector, i.e. people living in Parque Real district, is supplied solely from the well Parque Real I, until the point at which its water is mixed with water from Parque Real II. There is no pump at well Parque Real II that is able to add in the fluoride and chlorine. Therefore, the following procedure is adopted: water from the well Parque Real I is chlorinated and fluoridated with at least twice the recommended quantity, so that when its water is mixed with water from Parque Real II, it will be distributed to the remainder of the population with a concentration that is within the limits considered acceptable, but only from this point onwards ${ }^{20}$.

McDonagh, et al. ${ }^{12}$ (2000) estimated that, in an area with water fluoridated at $1 \mathrm{mg} / \mathrm{L}, 13 \%$ of the individuals exposed presented fluorosis. Results confirming this estimative were found by Heintze, et al. ${ }^{7}$ (1998), in the municipalities of Garça $(0.9 \mathrm{mg} / \mathrm{L})$, and Bauru $(0.64 \mathrm{mg} / \mathrm{L})$, with fluorosis prevalence of $13.3 \%$ and $6.8 \%$, respectively. In the same year, Campos, et al. ${ }^{3}$ observed $14.64 \%$ in Brasília $(0.8 \mathrm{mg} / \mathrm{L})$. However, it should be noticed that Maltz and Farias ${ }^{13}$ (1998) found fluorosis prevalence of $22 \%$ in Brasilia, and Tavares and Bastos $^{22}$ (1999) found 31.30\% in Bauru. These two latter studies obtained results that differed from those of Heintze et al. ${ }^{7}$ and Campos, et al. ${ }^{3}$, from the same cities, Bauru and Brasilia, in the same year (1998). 
According to some authors, the risk of dental fluorosis attributable to fluoridation ranges from 13.2 to $39.6 \% \%^{8,9,10}$. Results from studies carried out in Brazil have confirmed this estimated risk when water fluoridation was correlated with the prevalence of dental fluorosis. Similar prevalences of dental fluorosis were observed in different studies: Tomita, et al. ${ }^{23}$ in the municipality of Piratininga $(1.05 \mathrm{mg} / \mathrm{L} \mathrm{F}$ in public water supply) was 34.44\%; Maltz, et al. ${ }^{14}$ (2000) in Arroio do Tigre ( $\leq 0.3 \mathrm{mg} / \mathrm{L} \mathrm{F}), 29.7 \%$ and Porto Alegre (between 0 and $1.20 \mathrm{mg} / \mathrm{L} \mathrm{F}$ ), 32.6\%; Pereira, et al. ${ }^{18}$ (2001) in Piracicaba (0.7 mg/L F, 31\% and Iracemapolis ( $\leq 0.3 \mathrm{mg} / \mathrm{L} \mathrm{F})$, $10 \%$; Moysés, et al. ${ }^{15}$ (2002) in Curitiba ( $\left.0.7 \mathrm{mg} / \mathrm{L} \mathrm{F}\right), 23 \%$. The prevalence of dental fluorosis found in the present study, in a district of Bauru (0.9 mg/L F) was 33\% (Table 2).
When discussing dental fluorosis and intending to compare results, it is important to consider that some factors may interfere with the definition of the prevalence of disease: (1) the methodology used for the epidemiological survey, where calibration of examiners is essential; (2) the period of risk for the occurrence of fluorosis and therefore the place and date of birth of the population examined; and (3) the risk factors for fluorosis ${ }^{1}$. However, there are still no established scientific dose-response parameters for predicting the risk for dental fluorosis ${ }^{11}$. Therefore, the results from epidemiological surveys may even be compared, but it is important to carefully observe the situation in each place according to its peculiarities, as well as the risk factors that are common to all such locations.

TABLE 2- Percent prevalence of dental fluorosis according to age, gender and degree of fluorosis in a district of Bauru. 2004

\begin{tabular}{|c|c|c|c|c|c|c|c|}
\hline Age & Gender & TF0 & TF1 & TF2 & TF3 & TF4 & n (\%) \\
\hline \multirow[t]{2}{*}{7} & $M$ & 2 & 0 & 0 & 0 & 0 & $2(3.8)$ \\
\hline & $\mathrm{F}$ & 4 & 2 & 0 & 0 & 0 & 6 (11.5) \\
\hline \multirow[t]{2}{*}{8} & M & 1 & 0 & 0 & 0 & 0 & $1(2.0)$ \\
\hline & $\mathrm{F}$ & 1 & 0 & 0 & 0 & 1 & $2(3.8)$ \\
\hline \multirow[t]{2}{*}{9} & $M$ & 0 & 0 & 0 & 1 & 0 & $1(2.0)$ \\
\hline & $\mathrm{F}$ & 4 & 2 & 2 & 0 & 0 & 8 (15.0) \\
\hline \multirow[t]{2}{*}{10} & M & 3 & 0 & 0 & 0 & 0 & $3(5.8)$ \\
\hline & $\mathrm{F}$ & 5 & 0 & 1 & 1 & 0 & 7 (13.0) \\
\hline \multirow[t]{2}{*}{11} & $M$ & 2 & 0 & 0 & 2 & 0 & $4(7.7)$ \\
\hline & $\mathrm{F}$ & 2 & 0 & 1 & 0 & 0 & $3(5.8)$ \\
\hline \multirow[t]{2}{*}{12} & M & 3 & 0 & 0 & 0 & 0 & $3(5.8)$ \\
\hline & $\mathrm{F}$ & 3 & 1 & 0 & 1 & 0 & $5(9.6)$ \\
\hline \multirow[t]{2}{*}{13} & $M$ & 1 & 0 & 0 & 0 & 0 & $1(2.0)$ \\
\hline & $\mathrm{F}$ & 1 & 0 & 0 & 0 & 0 & $1(2.0)$ \\
\hline \multirow[t]{2}{*}{14} & $M$ & 0 & 0 & 0 & 0 & 0 & $0(0.0)$ \\
\hline & $F$ & 2 & 1 & 0 & 0 & 0 & $3(5.8)$ \\
\hline \multirow[t]{2}{*}{15} & M & 0 & 0 & 0 & 0 & 0 & $0(0.0)$ \\
\hline & $\mathrm{F}$ & 1 & 0 & 0 & 1 & 0 & $2(3.8)$ \\
\hline TOTAL & & 35 & 6 & 4 & 6 & 1 & $52(100.0 \%)$ \\
\hline
\end{tabular}

TABLE 3- Percentages of the different degrees of dental fluorosis, according to tooth group, in schoolchildren in a district of Bauru. 2004

\begin{tabular}{|c|c|c|c|c|c|c|}
\hline \multirow[t]{2}{*}{ Dental Group } & \multirow[b]{2}{*}{ TFO } & \multirow[b]{2}{*}{ TF1 } & \multicolumn{2}{|c|}{ Degree of Fluorosis } & \multirow[b]{2}{*}{ TF4 } & \multirow[b]{2}{*}{$\mathbf{n}$} \\
\hline & & & TF2 & TF3 & & \\
\hline Incisors & 75 & 11.5 & 3.8 & 9.6 & 0 & 52 \\
\hline Canines & 82.8 & 3.4 & 6.9 & 6.9 & 0 & 29 \\
\hline Premolars & 65.7 & 11.4 & 14.3 & 5.7 & 2.9 & 35 \\
\hline Molars & 94.1 & 3.9 & 0 & 2 & 0 & 51 \\
\hline
\end{tabular}


The main risk factor for dental fluorosis is the increased fluoride intake, due to the large availability from several sources, as recorded from the 1970s onwards. Until then, the only source of systemic exposure to fluoride that could reach everyone was fluoridated water. From the 1980s onwards, fluoridated toothpaste started to be used on a large scale, thus becoming an important source of fluoride intake. In addition to this, other sources of exposure to fluoride include mouthwash solutions, some products used in dental offices, infant formulas and some foods and drinks prepared with fluoridated water ${ }^{1,11,14,18}$.

The association between fluoridated water and fluoridated toothpaste must be considered when assessing the risk for dental fluorosis ${ }^{1,11,14,18,19}$. Studies conducted by Maltz, et al. ${ }^{14}$ (2000) and Pereira, et al. ${ }^{18}$ (2001) have suggested the importance of the association of these two factors. In the first study, (Maltz, et al. ${ }^{14}$, 2000), it was observed that in Porto Alegre (fluoridated) and Arroio do Tigre (non-fluoridated cities), between the years 1987 and 1998 there were increases in the prevalence of fluorosis from $7.7 \%$ to $32.5 \%$ and from 0 to $29.7 \%$, respectively. The second study, carried out in Piracicaba and Iracemapolis in the years 1991, 1995 and 1997, identified an increase in the prevalence of fluorosis of the order of 51.9\% (20.4\% to 31\%) in Piracicaba (fluoridated), and to five times the initial prevalence (2\% to $10 \%$ ) in Iracemapolis (non-fluoridated) ${ }^{17}$. One important finding observed in both studies is that there was an increase in the prevalence of fluorosis in all these cities, but the severity was always greater where there was fluoridated water. It must be highlighted, however, that the severity of dental fluorosis is usually low in these studies and the affected people do not consider it as a problem.

The schoolchildren from Parque Real district presented an expressive prevalence of dental fluorosis in the different tooth groups, with involvement going from the maxillary and mandibular central incisors to the premolars and canines and as far as the molars (Table 3). The severity was also noticeable, ranging from TF1 (11\%) to TF4 (2\%) (Table 2). In the studies by Maltz, et al. ${ }^{14}$ (2000) and Pereira, et al. ${ }^{18}$ (2001), the severity was lower. One matter relating to the prevalence and severity of fluorosis that has had much discussion is the association between the time required for a given group of teeth to form and the length of exposure fluoride. According to Fejerskov, et al. ${ }^{6}$ (1994), this is the reason why the premolars present greater prevalence of fluorosis, resulting from the longer time required for maturation of this tooth. These matters deserve attention and need to be evaluated, considering that the sample for this study came from a peripheral district, where water fluoridation is one of the few regular sources of fluoride intake and where there is only occasional and infrequent use of toothpaste.

The preventive effects of fluoride, largely recognized in Public health, are greater when water is used as the vehicle, due to the reach of the method, its effectiveness, cost and frequency of intake $e^{5,15,16,17,18}$. In addition, according to the Centers for Disease Control and Prevention (CDC), US, fluoridation of the public water supply is one of the top ten important public health measures in the twentieth century.
According to the CDC, the control of dental caries in children by using fluoridated water ranges from $40-70 \%$. Furthermore, it reduces between 40 and $60 \%$ the number of lost teeth in adults. The benefits of water fluoridation are proportionally higher for people that do not have regular access to other sources of fluoride ${ }^{5}$. Thus, it is important that water fluoridation is adequately implemented and maintained with a permanent system of monitoring.

\section{CONCLUSIONS}

The results of the present study reinforce the importance of monitoring the fluoridation of water supplies, as well as the need for epidemiological follow-ups of the prevalence of dental fluorosis, in order to better understand and prevent this disease.

\section{REFERENCES}

1- Buzalaf MAR, Cury JA, Whitford GM. Fluoride exposures and dental fluorosis: a literature review. Rev Fac Odontol Bauru. 2001;9(1/ 2):1-10.

2- Buzalaf MAR, Granjeiro JM, Damante CA, Ornelas F. Fluctuations in public water fluoride level in Bauru, Brazil. J Public Hlth Dent. 2002;62(3):173-6.

3- Campos DL, Farias DG, Toledo OA, Bezerra ACB. Prevalência e fluorose dentária em escolares de Brasília - Distrito Federal. Rev Odontol Univ São Paulo. 1998;12(3):225-30.

4- Cangussu MCT, Narvai PC, Fernandez RC, Djehizian V. A fluorose dentária no Brasil: uma revisão crítica. Cad Saúde Pública. 2002;18(1):1-15.

5- Centers for Disease Control and Prevention. Achievements in public health, 1900-1999: fluoridation of drinking water to prevent dental caries. Morb Mort Wkly Rep. 1999;48(41):933-40.

6- Fejerskov O, Baelum V, Manji F, Moller IJ. Fluorose dentária. São Paulo: Editora Santos; 1994.

7- Heintze SD, Bastos JRM, Bastos RS. Urinary fluoride levels and prevalence of dental fluorosis in three Brazilian cities with different fluoride concentrations in the drinking water. Community Dent Oral Epidemiol. 1998;26:316-23.

8- Heller KE. Water consumption in the United States in 1994-1996 and implications for water fluoridation policy. J Public Hlth Dent. 1999;59:11-3.

9- Jackson RD. Dental fluorosis and caries prevalence in children residing in communities with different levels of fluoride in the water. J Public Hllth Dent. 1995;55:79-84.

10- Lewis DW, Banting DW. Water fluoridation: Current effectiveness and dental fluorosis. Community Dent Oral Epidemiol. 1994;22:1538 .

11- Lima YBO, Cury JA. Ingestão de flúor por crianças pela água e dentifrício. Rev Saúde Pública. 2001;35(6):576-81.

12- MacDonagh MS, Whiting PF, Wilson PM, Sutton AJ, Chestnutt I, Cooper, et al. Systematic review of water fluoridation. Br Med J. 2000; 321(7265):855-9. 
13- Maltz M, Farias C. Fluorose dentária em escolares de quatro cidades brasileiras com e sem água artificialmente fluoretada. Rev Fac Odontol de Porto Alegre. 1998;39(2):18-21.

14- Maltz M, Silva BB, Schaeffer A, Farias C. Prevalência de fluorose dentária em duas cidades brasileiras, uma com água artificialmente fluoretada e outra com baixo teor de flúor, em 1987 e 1997/98. Rev Fac Odontol de Porto Alegre. 2000;42(2):51-5.

15- Moysés SJ, Moysés ST, Allegretti ACV, Argenta M, Werneck R. Fluorose dental: ficção epidemiológica? Rev Panam Salud Publica. 2002;12(5):339-46.

16- Murray JJ. O uso correto de fluoretos na saúde pública. São Paulo: Ed. Santos; 1992. 131p.

17- Narvai PC. Vigilância Sanitária da fluoretação das águas de abastecimento público no município de São Paulo, Brasil, no período de 1990-1999. Tese (Livre-docência). Faculdade de Saúde Pública, Universidade de São Paulo, São Paulo; 2001.149p.

18- Pereira AC, Mialhe FL, Bianchini FLC, Meneghim MC. Prevalência de cárie e fluorose dentária em escolares de cidades com diferentes concentrações de flúor na água de abastecimento. Rev Bras Odontol Saúde Coletiva. 2001; 2(1):34-9.

19- Prendrys DG. Risk of enamel fluorosis in non-fluoridated and optimally fluoridated populations: considerations for the dental professional. J Am Dent Assoc. 2000;131(6):746-55.

20- Ramires I. Avaliação da concentração de flúor na água de abastecimento público, antes e depois dos procedimentos de fluoretação. Dissertação (Mestrado) - Faculdade de Odontologia de Bauru. Universidade de São Paulo; 2004. p.189.

21- São Paulo (Estado). Secretaria de Saúde. Resolução SS-250, de 15/ 08/1995. Diário Oficial do Estado de São Paulo; 16/08/1995, seção I, p.11.

22- Tavares PG, Bastos JRM. Concentração de flúor na água: cárie, fluorose e teor de fluor urinário em escolares de Bauru - SP. Rev Assoc Paul Cirur Dent. 1999;53(5):407-15.

23- Tomita NE, Panighel CPMA, Narvai PC, Lopes ES. Implicações da vigilância sanitária à saúde sobre a ocorrência de fluorose dental. Rev ABO Nac. 1995;3(5):318-23.

24- Viegas AR, Viegas I, Castellanos RA, Rosa AGF. Fluoretação da água de abastecimento público. Rev Ass Paul Cirur Dent. 1987;41(4):202-4.

25- Whitford GM et al. Plaque fluoride concentrations in a community without water fluoridation: effects of calcium and use of a fluoride or placebo dentrifice. Caries Res. 2005;39(2):100-7. 